\title{
Effective teachers' personality in strengthening character education
}

\author{
Lukman $^{1}$, Marsigit ${ }^{2}$, Edi Istiyono ${ }^{3}$, Badrun Kartowagiran ${ }^{4}$, Heri Retnawati ${ }^{5}$, Hanif Cahyo Adi \\ Kistoro $^{6}$, Himawan Putranta ${ }^{7}$ \\ ${ }^{1}$ Department of Educational Research and Evaluation, Graduate School, Universitas Negeri Yogyakarta, Indonesia \\ ${ }^{1}$ Department of Islamic Education, Faculty of Islamic Studies, Universitas Islam Indonesia, Indonesia \\ 2,3,4,5 Department of Educational Research and Evaluation, Graduate School, Universitas Negeri Yogyakarta, Indonesia \\ ${ }^{6}$ Department of Islamic Education, Faculty of Islamic Religion, Universitas Ahmad Dahlan, Indonesia \\ ${ }^{7}$ Department of Educational Sciences, Graduate School, Universitas Negeri Yogyakarta, Indonesia
}

\section{Article Info}

Article history:

Received Dec 26, 2020

Revised Apr 2, 2021

Accepted Apr 14, 2021

\section{Keywords:}

Character

Discipline

Joyful

Phenomenology

Respectful

Role model

\begin{abstract}
Personality is a silent sedentary nature, which affects the attitudes and behavior of every individual. For a teacher, personality will appear as a hidden curriculum, which affects how to teach and educate. This phenomenological research aimed to interpret the characteristics of effective teachers' personality in strengthening character education. The participants in this study were 17 elementary, secondary, and high school teachers from nine districts in Indonesia. This participant was selected using purposive sampling technique (teachers who have more than 10 years of teaching experience). Data collection was carried out by interview. Qualitative data analysis was performed using the ATLAS.ti software. The data analysis stages in this study were data coding, data classification, and data interpretation. This study found 12 personality characteristics of teachers that are effective in strengthening character education, include able to behave as friends, able to be roles model, able to understand lessons, discipline, respectful of students, treat students impartially in terms of sanctions, patient, relaxed, willing to pursue life-long learning, master the skill of educating character, not known as fierce teachers, and perceived as joyful teachers. The effective teacher personality can provide understanding and improvement of character education in schools.
\end{abstract}

This is an open access article under the $\underline{C C B Y-S A}$ license.

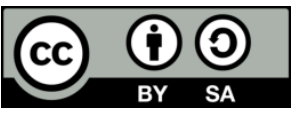

\section{Corresponding Author:}

Lukman

Department of Educational Research and Evaluation, Graduate School

Universitas Negeri Yogyakarta

Yogyakarta 55281, Indonesia

Email: lukman.2018@student.uny.ac.id; lukman.ahmadirfan@uii.ac.id

\section{INTRODUCTION}

The teacher is the main actor in the learning process. It is teachers who consider effective learning strategies to be applied [1], [2]. A large number of variations in the quality of teaching are explained by the characteristics of teachers [3], teachers are central in the process teaching and learning [4], teachers have a major role in building student personality [5], teachers are learning managers [6] in a large system of education that enlightens students. So, they can behave in ways that are guided by conscience, genuine appearance without falsehood, caring about the upholding of social ethics and being a personal figure who has a high appreciation of the problems of humanity, honesty, democratization, tolerance, and peace of life, and can be responsive to all the problems facing society and the nation. In short, teachers are very influential 
in giving birth to people who are firmly principled, politely interacting, intelligent in argumentation, and graceful in daily life. Therefore, it is teachers who must be improved in quality to improve student achievement [7]. The expectations of teachers bear complex demands on their quantity and quality. In terms of quantity, the number of teachers still does not meet good standards due to the problem of equity. In terms of quality, the expectations of these demands are regulated in Law Number 14 of 2005 on Teachers and Lecturers in article 10 paragraph 1 which states that teachers' competence referred to in Article 8 includes pedagogical competence, personality competence, social competence, and professional competence obtained through professional education [8].

Therefore, the development of the four teacher competencies is the mandate of the Law that must be realized. Among the four competencies, personality competence is very important to be studied for the continuous development of character education because personality traits are more sedentary [9] and continuously will affect the flow of learning as the character of teachers influences student achievement [10]. Personality competency is conceptualized as a personal ability that reflects a steady, stable, mature, wise, and authoritative personality, being an example to students and having good character. In Minister of Education Regulation No. 16 of 2007, personality competencies include five main competencies, include acting by religious, legal, and social norms; presenting oneself as an honest, noble, and exemplary person for students, and the community; presenting oneself as a stable, mature, wise, and authoritative person; demonstrating work ethic, high responsibility, pride in being a teacher, and self-confidence; and upholding the code of ethics of the teaching profession [11]. The urgency of personality in the competency domain is very important because it becomes a foundation for teachers to develop three other competencies. As research on personality by Göncz [12] shows, teachers' personality is the best starting point when considered together with current knowledge about small social group management and aspects of learning theory. The development of the teachers' personality is paralleled by the development of all other aspects of teacher professionalism [13].

Teachers' personalities certainly have high expectations for student success. Previous research shows that teachers who have high expectations differ in influence from those who have low expectations of achievement [14]. Teachers' personality continues to change throughout life due to genetic and environmental factors, including cultural context [15]. Specific personality traits contribute to effective teaching [16]. There is a significant relationship between teacher personality types [17]. Intuition-sensing temperament types are the best predictors for teaching effectiveness [18]. Students like intuition and thinking while learning and like intuition, thinking, and feeling while teaching [19]. Experienced teachers are significantly higher in teacher effectiveness than less experienced ones [20]. The results of the previous studies above indicate that teachers' personality becomes a determining factor in choosing models, strategies, and learning media, including in character education which is very important in the digital age. Based on these results and changes in the characteristics of learning of generation $\mathrm{Z}$ in the disruption era, it is of significance to research the personality of teachers and its impacts on character education.

\section{LITERATURE REVIEW}

\subsection{The urgency of the teacher's personality competence}

Being concerned that the role of teachers will be replaced by information technology and artificial intelligence in the era of industry 4.0, the Indonesian Ministry of Education and Culture launches a discourse on strengthening learning innovations by giving teachers the broadest possible role. This is indeed an interesting discourse because teachers are the spearhead in a large system of education that interacts with students [21]. Teachers have a major role in building student personality and they are learning managers [22]. Personality competencies provide a basis for teachers to develop three other competencies. Teacher personality is the best starting point when considered together with current knowledge about small social group management and aspects of learning theory [23]. Because personality traits are more sedentary, they will continuously influence the flow of learning as teachers' character influences student performance [24]. Teachers who have high expectations have different influence compared with teachers who have low expectations of achievement [25].

Theoretical and research literature that discusses personality and learning has been done for almost a century [26]. Among the results in this century was the findings of Stanton in 1974 that students tend to do better under the teaching method, the latter seeing themselves as more tense and anxious than students tending to perform better under the previous method [27]. Next research by Murray and his colleagues in 1990 studied 29 personality traits of teachers in learning at university, among the results were specific personality traits that contributed to effective teaching that were significantly different for different types of courses [28]. Such high demands for teacher roles have occurred perhaps since the emergence of the title of teacher, among which are expressed in the book "Teacher Self-Evaluation: Teachers in Their Own Mirror" 
published 1993 [29] that teachers are asked to develop high-level thinking in students and to help them develop independent learning. They are also responsible for the moral development of their students.

Other studies investigating the influence of introverted and extroverted teachers' personalities on their instructional proximity showed a relationship between extroverted teachers' personality and their use of verbal closeness positive correlation $(\mathrm{r}=0.7, \mathrm{p}<0.03)$ and extroverted personality and use of non-verbal closeness $(r=0.7, r=0.75, p<0.01)$ [30]. Other studies reviewed 47 published studies and looked back on online teaching and learning since 2008, finding motivated interaction between instructors and students, instructors who were well prepared and fully supported would stimulate ongoing discussion [31]. This shows that because personality traits are more sedentary, they will continuously influence the flow of learning and then on learning achievement [32]. Research results in 2017 show that teachers who teach empathically help students to grow in facing various challenges at various levels [33].

Findings of teacher personality obtained in the context of current personality theory can serve as the best starting point for a more comprehensive theory of teacher personality psychology in educational psychology, especially when considered together with current knowledge of small social group management and aspects of learning and development theory. As such, the current review can serve as a basis for a separate field in school psychology that focuses on the psychological aspects of the pedagogical profession. Study conducted by Khan and his colleagues revealed that there was no significant effect of the combination of both personality traits and learning styles on the prediction of academic achievement among school students. The same thing applies to differences in personality traits and learning styles between male and female students is not significant too [34], personality competence has an effect of $26 \%$ on learning achievement in economics [35], the use of multicultural-based short story appreciation, which is part of the personality of openness, is more effective than the use of textbooks to teach prose-fiction appreciation [36].

\subsection{The relationship between character education and teacher personality}

Based on the explanation above, it can be seen that personality competence is a personal or personal ability of the teacher that reflects a mature, solid, dignified, stable, and wise personality. This kind of character will certainly lead to modeling concepts for students. Teachers who are fond of personality will tend to be used as examples by students [36]. In religious teachings, it is identical to the concept of uswatun hasanah (a good role model), where the teacher who teaches must provide a good example in his faithful words and deeds. The teacher's personality competencies will certainly make students feel happy, comfortable and interested in the lessons that are delivered. In the end, the teacher's goal in providing subject matter will be more easily accepted and the results will be maximized [37]. The relationship between teacher personality competence and character education will certainly be carried out well if the teacher also has good personality competence.

\section{RESEARCH METHOD}

\subsection{General background}

The approach of this study is a qualitative type of phenomenology with a constructivist paradigm, which investigates the personality of teachers in their natural setting as a teacher, and then interpret it. Understanding and interpreting teachers should ideally have someone who is obeyed and emulated in the era of disruption. The qualitative model used in this study is a phenomenology because phenomenology describes the participant's direct experience, especially like a phenomenon [37].

\subsection{Participant}

Primary sources of participants are teachers in madrasas or religious teachers in schools with criteria of having more than 10 years of teaching experience. The number of participants was 12 people divided into 8 male teachers and 4 female teachers. The sampling technique used purposive sampling. Criteria for 10 years of teaching experience is to ensure participants' experience in dealing with twists and turns as a teacher. The first key informant was asked his willingness to be an informant and his availability to be interviewed, the next participant determined by snowball technique. Interviews are conducted in a structured and natural manner that allows participants to convey and express their experiences, opinions, and feelings naturally, some teachers are given interview questions and answer them in writing using communication technology. Researchers also used Focus Group Discussion (FGD) to dig deeper into the data. Table 1 shows the participant profile. 


\begin{tabular}{|c|c|c|c|c|c|}
\hline \multirow{2}{*}{ No. } & \multirow{2}{*}{ Name } & \multicolumn{2}{|c|}{ Gender } & \multirow{2}{*}{ School } & \multirow{2}{*}{ Total } \\
\hline & & Male & Female & & \\
\hline 1. & $\mathrm{~L}$ & 1 & - & Madrasah & 1 \\
\hline 2. & $\mathrm{NH}$ & 1 & - & Madrasah & 1 \\
\hline 3 & $\mathrm{R}$ & 1 & - & Madrasah & 1 \\
\hline 4 & DM & 1 & - & School & 1 \\
\hline 5 & DS & - & 1 & School & 1 \\
\hline 6 & ST & - & 1 & School & 1 \\
\hline 7 & $\mathrm{AM}$ & - & 1 & School & 1 \\
\hline 8 & $\mathrm{HC}$ & 1 & - & Madrasah & 1 \\
\hline 9 & BY & 1 & - & Madrasah & 1 \\
\hline 10 & JN & 1 & - & School & 1 \\
\hline 11 & $\mathrm{AJ}$ & 1 & - & School & 1 \\
\hline 12 & AN & 1 & - & School & 1 \\
\hline Total & & & & & 12 \\
\hline
\end{tabular}

Note: The number of participants was 12 teachers

\subsection{Instrument and procedures}

The procedure of this research was carried out by preparing by making the interview protocol as a guide for conducting interviews and FGD consisting of four main parts, namely the researchers' introduction, interview questions, confirmation of the results of the interview, and saying thank you. In the introduction, the researcher was introduced as a doctoral student who was researching Islamic personality. In the interview questions, the researchers first asked about "which is more effective between the teacher's personalities than the learning model in student character education?" The next question flowed by the development of the interview while still considering interview guidelines. Ethical procedures in conducting research were carried out by asking for permission to the regional office of the Ministry of Religion of the Special Province of Yogyakarta, schools, and asking for the willingness of participants to be interviewed and asking for permission to do the recording. There were no obstacles to this permit process. The researcher also said that the results of this study would not reveal the identity of the informant. The technique of collecting data in two ways, namely interviews and group discussions. In-depth interviews use an interview guide that contains questions about the teacher's personality competencies. The questions asked also reveal about the learning strategies carried out by the teacher in character education. Data collection with group discussions was carried out online by creating a special group in online media. In the group discussion the researcher used a discussion guide in the form of a check list of data about the personality abilities of the teacher, the teaching strategies and techniques used, the obstacles and challenges faced and other competency abilities that were used by the teacher to achieve the expected character education targets.

\subsection{Data analysis}

The data analysis technique was carried out according to the opinion of Moustakas [38] with the following procedure include the researcher described the results of his research. The researcher then determines the theme, each detailed statement has an equivalent value in the theme and develops these details by not doing repetition. Grouping the data into meaningful units, the researcher breaks down the units and writes a textural description of his experience, including careful examples. Reflecting his thoughts and use imaginative variations, look for all the possible meanings and through divergent perspectives, consider the frame of reference, and construct how phenomena are experienced. Constructing all of his explanation of the meaning and essence of his experience. The process is the initial step of the researcher expressing his experience and then followed by the experience of all participants. After all these steps are done, the researcher then writes the combined description. This analysis technique was done with the help of ATLAS.ti qualitative data analysis software. The stages and processes of the analysis technique can be observed in Table 2.

Table 2. Data analysis process

\begin{tabular}{cll}
\hline Step & \multicolumn{1}{c}{ Activity } & \multicolumn{1}{c}{ Results } \\
\hline First & $\begin{array}{l}\text { Determine the theme } \\
\text { Make important statements according to the results of data collection }\end{array}$ & Obtained the main theme studied \\
Second & $\begin{array}{l}\text { Main themes grouping } \\
\text { Detailing in detail each of the themes that are obtained } \\
\text { Write a description of each theme }\end{array}$ & $\begin{array}{l}\text { Find the main theme under study and write a } \\
\text { description of it }\end{array}$ \\
Third & $\begin{array}{l}\text { Linking themes based on the results of data collection } \\
\text { Fourth } \\
\text { participants }\end{array}$ & $\begin{array}{l}\text { Intertwined explanations between themes } \\
\text { Complete descriptions of all themes obtained } \\
\text { based on the experiences of all participants }\end{array}$ \\
\hline
\end{tabular}




\title{
4. RESULTS
}

This interview conducted at the end of October, 2019. At that time, the atmosphere was hot and stinging, but was slightly muffled by the shadow of the prayer mosque, especially after the prayer: the faces of the teachers were refreshed after the ablution, the shady faces after putting his forehead shed the ego, and increasingly distancing the frenzy of chanting prayers and surrender of life and death to the Owner of the Soul. The mosque at the regional level ministry office was fuller because of the presence of 24 religiousbased high school curriculum teachers attending the event. The researchers selected one of the teachers, then carefully greets him. This choice is based on instinctive and interest in seeing the teacher, how he greeted with a nod of his head even though we both never met. The researchers thought the teacher was a friendly person. Smiling and nodding when meeting in this office is something normal, but researchers see the shade of his face as more interesting than others. This was proven when the researcher approached and introduced himself, he kindly welcomed and answered the questions of the researchers. He chose to sit down and answer questions carefully. Occasionally he became fast because of his enthusiasm, and occasionally he answered with a slow tempo because he chose the right diction.

The researchers started with the first question to draw his attention to that this research is important. The researcher asked, "Is the development of student character influenced by the learning model by the teachers' character?" participant L replied:

\begin{abstract}
"Many are also influenced by the character of teachers, meaning that the character of teachers can give an example, then with that example make a program for habituation of good personality. For example, we smile and greet and say hello to the students, then they will get used to doing the same to us. Another example is by throwing the trash to its place; this might seem trivial but it's extraordinarily useful in inviting children to dispose of trash in its place ... And many other examples... With all these good examples, students would think how come the teacher just gives a smile and polite greeting to his students, automatically they will get impacted ... oh I am respected by my teacher, so I'll also respect the teacher".
\end{abstract}

In interviews with another participant initials DS, what was conveyed by the teacher with a shady face was indeed the main keywords: and examples of small things. According to this participant, character education is effective when done by providing examples of consistent behavior, the similarity in sanctions, everything at school is done familiarly, and problems are solved without judging beforehand. When asked which one namely $\mathrm{NH}$, is more effective between teachers' personality and the learning model in character education, he answers as the researchers suspect, they support each other, but when the researcher asks again, which one he prioritizes, participant AM answered that it is the teachers' personality. He gives the reason that for his pleasant personality, without fun learning models, he will still be liked by his students. The pleasure of students in learning will facilitate any learning model while a fun learning model will feel stiff if the personality is lacking.

His opinion turned out to be substantially the same as 12 of the 17 teachers the researchers asked. However, five people were not willing to provide information for personal reasons. The eleven teachers who agreed revealed various reasons, even though some gave arguments, the calm personality of the teacher facilitated the entire learning process because the calm teachers had the best capital in choosing learning models, solving problems in class, even problems in school in general. Of the seven FGD participant teachers and six informants interviewed with the opening question "which is more effective teachers' personality in character education?" Five of these teachers continue to insist that character education must be carried out by combining the two. A fun-boosting model is more effective when it is done by a teacher who is known by students as a teacher who is patient, friendly, family personality. Teachers who are patient, friendly, and have family personality must have expertise in delivering fun learning. Two teachers choose that the learning model is more important than personality. Participants chose this argument with joy because children are easy to receive knowledge. Other teacher, six informants revealed that personality is more important and takes precedence in the character education process, and then it will become more effective if synergized with a varied learning model, which is based on a fun learning model. Some answers from the informants HC are as:

\footnotetext{
"In my opinion ... both attitude and learning model has a great influence on learning delivered to students ... in term of the attitude, teachers must first be a good example for their students ... then in terms of the learning model, it must be appropriate and fun, it must motivate children so that learning can be delivered to the maximum level".
} 
Informants JN use the word synergy between patient and friendly personalities and "sustained" learning models that are fun to be effective. With this synergy, learning will last long in marrying knowledge and the character of students. Others hesitantly said, as expressed by participant AJ that teachers' personality remains the most important, but immediately added that it must be accompanied by the support of the skill of delivering pleasant learning.

"In my opinion both are important, both must support each other. But if I have to choose, attitude is more important, but it must be also supported by the learning model because the attitude of the teacher is imitated by students, so, the teachers' attitude must be a good example. At the same time, learning models must be also by the material, must be appropriate to please the students".

Some participants firmly said that personality is the main thing in the teaching profession. According to him, the learning model that continues to be practiced without innovation will be boring, whereas personality is never boring anywhere and anytime. The following quote is from the original is the result of an interview with AN that:

\begin{abstract}
"In my opinion, patience and friendliness are the main spirits, the model is a way and a learning model can succeed in a problem of character, but if practiced continuously without innovation students will also get bored, but other people are never bored with friendly and patient people".
\end{abstract}

From the results of the analysis, the researcher obtained several characteristics of teachers that are effective in character education, include can behave as friends, can be a role model, can understand lessons, discipline, respectful of students, treat the students impartially in terms of sanctions, patient, relaxed, willing to pursue life-long learning, master the skill of how to educate character, not known as fierce teachers, perceived as fun teachers. Of the twelve characters, there are only two that are not categorized in personality characteristics, which can understand the lesson and master the skills in how to educate students' characters. The other ten characteristics are personality characteristics that tend not to be obtained from learning in formal teacher lectures and training which lasts 1 or 2 days. Researchers find, however, that teachers' personality is very important in character education tends to get less attention from both the teachers themselves, school management, and also the government. This can be seen from: 1) The difficulty of the teacher in defining explicitly what is personality, so that mutual mistakes for mistakes are made by researchers by mixing the definition of attitude, character, and personality; 2) Unclear school and government programs in increasing teacher personality competency systematically and continuously.

Another interesting result of the research is that some informants thought that non-trait personality remained unchanged as the opinions of experts, but the development of personality was the duty of the teacher for life. Functional personality in character education is patience, family, and calm. Not at all discussing teachers who are extroverted, introverted, sanguinis, and so on as personality theories that have been developing. Patience, kinship, and calmness are personality traits that can be sought to develop. All of the teachers selected by the researchers had more than ten years of teaching experience. If they every week have a teaching schedule in 20 hours of learning, recurring meetings take place very often and for a long time. When compared with a learning model that is applied repeatedly, naturally boredom will emerge. So, it is appropriate for experienced teachers to say that personality is more important than the learning model.

A calm personality is the main thing that must be possessed by teachers because it is sourced from calmness that will flow easily with all its variations. Teachers who tend to be angry and hard are a contradiction in learning success, especially in learning for strengthening character education. Personality is more important than the learning model since patience, familiarity and calmness are the foundation that is not quickly eroded by the presence of new learning models that will continue to develop. Meanwhile, the development of successive learning models will be easily lost in students' impressions, and what remains is patience, familiarity, and calmness of teachers. The virtue of this personality is not balanced with the ongoing coaching program for teachers. This can be seen from one informant's answer when asked whether the program this year is a personality improvement. He answered that his program was a student-friendly learning method. Some of the characteristics of effective teachers in education and strengthening character education can be explained simply in Figure 1. 


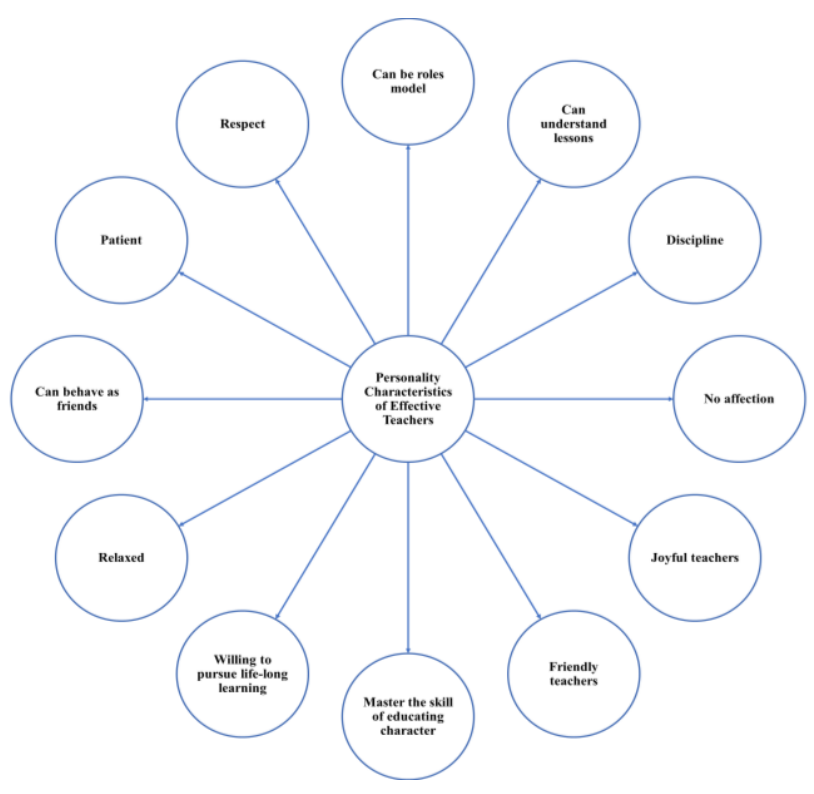

Figure 1. Personality characteristics of an effective teacher

Based on the picture above, it can be understood that in character education, figures and characters as well as teacher abilities greatly influence the improvement and strengthening of children's character. There are many aspects of personality competence that teachers must possess. Teachers are required to be able to be role models and friends of children. Have extensive knowledge, have disciplined behavior, respect students as well as be able to provide justice and be impartial. Have a strong will to learn and be able to educate well, as well as be a patient and relaxed person. Such character will make the teacher perceived by the child as a gentle and pleasant teacher.

In simple terms, the teacher's personality competence has several aspects, namely the teacher must be able to be a good role model, example or model (uswah), the teacher is able to provide motivation, the teacher is able to have extensive knowledge. Teachers are also able to be good administrators by applying disciplined behavior to their students. In addition, teachers are also required to be a catalyst by respecting different student opinions and providing a sense of justice for students. Another competency recommended for teachers is having a vision for the future with a high and strong willingness to learn so that students will be motivated and follow it. Finally, the teacher has a patient, gentle and pleasant character. With this competency, teachers are seen as the center of attention in learning because of their competencies. This makes it easier for teachers to provide material properly and to be able to provide comprehensive understanding to their students.

\section{DISCUSSION}

The latest research results that the authors accessed in 2019 show that personality types will allow teachers to consciously choose the appropriate approach to deal with different situations in their personal [39]. Also, research conducted in Germany that investigated 209 German mathematics teachers and 4,672 students who attended grades 7-10 (students aged 13 to 16 years) resulted in a large amount of variation in the quality of teaching explained by the characteristics of the teacher [40]. The intended teacher characteristics are cognitive ability, personality, professional knowledge, trust, and enthusiasm for teaching. Other research results show that two personality traits have a greater positive impact on students' perceptions of online learning, whereas neuroticism has significantly negative effects on online course participants. These results provide evidence that students with different personality traits have different preferences and experiences [41]. Observing the results of these recent studies on the role of teachers, it seems that the role of teachers will still be central in education. This is due to the role of teachers not only in providing information about knowledge, but in providing motivation, empathy, and emotional encouragement that come from other conscience. Therefore, it is very important to improve the teacher's quality, especially the more fundamental aspects, namely their personality because the development of technology presents many interesting things in acquiring knowledge while teachers' personality is more focused on character building. Teachers in the digital age are responsible for preparing a better, brighter, and progressive future generation [42]. 
The results of this research and those of research in many countries as mentioned above confirm that in Indonesia the same thing happened that the personality characteristics of teachers influence success in learning. Five of the most basic are patience, kinship, calmness, example, and always learning throughout life are not explicitly the same as the personality competencies that exist Ministerial Decree No. 16 of 2007 [11]. This seems to be a serious concern for policymakers. Changes in teacher personality competencies that must be possessed by teachers today are also due to changes in learning characteristics of generation $\mathrm{Z}$ who are currently students in junior and senior high schools. This is most likely caused by a change in paradigm and the way of learning of the current generation or generation Z. Teachers should become more enthusiastic learners because of changes in the characteristics of the generation they teach. They need to consider and choose effective learning strategies to be applied [43]. They also have a major role in building student personality [44]. Teachers are also learning managers [45]. A large amount of variation in the quality of teaching is explained by the characteristics of teachers [46].

Seventeen teachers, who have experienced teaching for more than 10 years, revealed that teachers' attitude in the learning process was more effective in character education. This is because the learning model used is to form attitudes and then lead to student behavior. The learning model that is used with a loud and fun, if you do not find examples/models/that are imitated and the absence of confirmation between the knowledgeable with reality results in disappointment. Often revealed knowledge without charity is like a tree that does not bear fruit, which will lead to disappointment. In a discussion about the disappointment of a student with his teacher, the researchers found a finding that teachers who were considered a student did not do what they taught, triggered student hatred, not only to the teacher even to what he taught. The value of teaching materials will be weakened by students, which if students do not find the foundation to return to the right decision, then it can be a wrong decision all his life. An adage that develops in Javanese culture says that even the teacher is emulated and imitated, which means that the teacher is trusted to learn from his behavior. This is a warning that becoming a teacher must be ideal in the assessment of students. If related to the findings of this study, it is very relevant if the teacher is a personal figure who integrates a fun learning model as well as a pleasant person. Other research results, teachers' difficulty in defining explicitly what is personality, causes ongoing difficulties to determine continuous self-improvement through self-evaluation. This is also caused by the ambiguity of thinking about the personality and norms of customs and religion that surrounds teachers. And, this is exacerbated by the lack of clarity in the school and government programs in increasing teacher personality competency systematically and continuously. If explored further, the main cause is the theory of personality that should be developed better. Theory, however, is very difficult to change, therefore this affects the absence of standard evaluation instruments for functional personalities that provide feedback for improving teacher personality.

\section{CONCLUSION}

Teachers' personality characteristics that are effective in strengthening character education include able to behave as friends, able to be a role model, able to understand learning, discipline, respectful of students, treated students impartially in terms of sanctions, patience, relaxed, willingness to pursue life-long learning, master the skill of educating characters, are not known as fierce teachers, and perceived as fun teachers. Of the 12 characters, there are only two that are not categorized in personality characteristics that can understand the lesson and master the skills in how to educate students' characters. Therefore, characteristics of effective teachers in character education should be synergized with the ability of teachers in fun learning models. Research on character education still has many aspects and dimensions that need to be studied further. The development and depth of themes, expansion of the scope of research, and various types of research will be able to add and enrich research results on the theme of character education. More diverse and complete research results will be a basic guideline for making policies in increasing the competence of teachers in general. The character of effective teachers revealed in this study becomes an interesting theme in character education. A strong character and personality are children's assets in facing increasingly complex global challenges. This research still has limitations in analyzing the strengthening and formation of children's character. There are many limitations and gaps that can be developed in future studies.

\section{REFERENCES}

[1] K. Goh, "What good teachers do to promote effective student learning in a problem-based learning environment," Australian Journal of Educational \& Developmental Psychology, vol. 14, no. 1, pp. 159-166, 2014.

[2] A. Kudryashova, et al., "Teacher's roles to facilitate active learning," Mediterranean Journal of Social Sciences, vol. 7, no. 1, pp. 460-471, 2016. 
[3] F. Baier, et al., "What makes a good teacher? The relative importance of mathematics teachers' cognitive ability, personality, knowledge, beliefs, and motivation for instructional quality," British Journal of Educational Psychology, vol. 89, no. 4, pp. 767-786, 2019.

[4] T. Wanner and E. Palmer, "Formative self-and peer assessment for improved student learning: the crucial factors of design, teacher participation and feedback," Assessment \& Evaluation in Higher Education, vol. 43, no. 7, pp. 1032-1047, 2018.

[5] A. H. Sayani, "My philosophy of teaching and learning," Open Access Library Journal, vol. 2, no. 12, pp. 1-9, 2015.

[6] I. Rindu and A. Ariyanti, "Teacher's role in managing the class during teaching and learning process," Script Journal: Journal of Linguistic and English Teaching, vol. 2, no. 1, pp. 83-100, 2017.

[7] O. S. Adewale, "Teaching personality as a necessary construct for the effectiveness of teaching and learning in schools: An implication for teacher development in the era of globalization," Journal of Education and Human Development, vol. 2, no. 2, pp. 15-23, 2013.

[8] Republic of Indonesia. Law of the Republic of Indonesia Number 14 of 2005, concerning Teachers and Lecturers. 2005.

[9] R. P. Corcoran and J. O'Flaherty, "Personality development during teacher preparation," Frontiers in Psychology, vol. 7, no. 1, pp. 167-175, 2016.

[10] C. M. Rubie-Davies, "Teacher expectations and perceptions of student attributes: Is there a relationship?" British Journal of Educational Psychology, vol. 80, no. 1, pp. 121-135, 2010.

[11] Minister of Education and Culture. Regulation of the Minister of National Education No. 16 of 2007, concerning Academic Qualification Standards and Teacher Competencies. 2007.

[12] L. Göncz, "Teacher personality: A review of psychological research and guidelines for a more comprehensive theory in educational psychology," Open Review of Educational Research, vol. 4, no. 1, pp. 75-95, 2017.

[13] E. Latipah, et al., "Scientific attitudes in Islamic education learning: Relationship and the role of self-efficacy and social support," Edukasia: Jurnal Penelitian Pendidikan Islam, vol. 15, no. 1, pp. 37-56, 2020.

[14] A. M. Flanagan, et al., "Achievement may be rooted in teacher expectations: examining the differential influences of ethnicity, years of teaching, and classroom behaviour," Social Psychology of Education, vol. 23, no. 6, pp. 1429-1448, 2020.

[15] H. Kim and J. Y. Sasaki, "Intercultural similarities and differences in personality development," in Personality Development Across the Lifespan. Academic Press, 2017, pp. 419-434.

[16] A. Fabbro, et al., "Effects of mindfulness training on school teachers' self-reported personality traits as well as stress and burnout levels," Perceptual and Motor Skills, vol. 127, no. 3, pp. 515-532, 2020.

[17] E. Latipah, et al., "How are the parent's involvement, peers and agreeableness personality of lecturers related to self-regulated learning?" European Journal of Educational Research, vol. 10, no. 1, pp. 1063-1074, 2021.

[18] H. R. Gordon and R. Yocke, "Relationship between personality characteristics and observable teaching effectiveness of selected beginning career and technical education teachers," Journal of Vocational and Technical Education, vol. 16, no. 1, pp. 47-66, 1999.

[19] C. Akdeniz and B. Erişti, "The relationship between elementary school teachers' personality types and their learning and instructional strategies," International Journal of Curriculum and Instruction, vol. 8, no. 2, pp. 41-63, 2016.

[20] N. Yazdanipour and M. Fakharzadeh, "Effective language teachers' characteristics as perceived by English language private institutes' administrators in Iran," The Qualitative Report, vol. 25, no. 8, pp. 3111-3128, 2020.

[21] H. C. Adi, M. Zulvia, and A. F. Asyha "Study on Teacher Competency and Education Linierity in Improving Student Learning Achievement in Gunung Tiga 1 State Elementary Schools and Ngarip Lampung 1 State Elementary Schools," (in Bahasa), Al-Tadzkiyyah: Jurnal Pendidikan Islam, vol. 10, no. 2, pp. 245-255, 2019, doi: 10.24042/atjpi.v10i2.5140.

[22] B. Lian, et al., "Teachers' model in building students' character," Journal of Critical Reviews, vol. 7, no. 14, pp. 927-932, 2020.

[23] E. Backman and D. M. Barker, "Re-thinking pedagogical content knowledge for physical education teachersimplications for physical education teacher education," Physical Education and Sport Pedagogy, vol. 25, no. 5, pp. 451-463, 2020.

[24] M. T. G. Knebel, et al., "Mediating role of screen media use on adolescents' total sleep time: A cluster-randomized controlled trial for physical activity and sedentary behaviour," Child: Care, Health and Development, vol. 46, no. 3, pp. 381-389, 2020

[25] J. Kaiser, et al., "The effects of student characteristics on teachers' judgment accuracy: Disentangling ethnicity, minority status, and achievement," Journal of Educational Psychology, vol. 109, no. 6, pp. 871-883, 2017.

[26] B. De Raad and H. C. Schouwenburg, "Personality in learning and education: A review," European Journal of Personality, vol. 10, no. 5, pp. 303-336, 1996.

[27] H. E. Stanton, "Teaching methods and student personality: The search for an elusive interaction," Instructional Science, vol. 2, no. 4, pp. 477-501, 1974.

[28] H. G. Murray, et al., "Teacher personality traits and student instructional ratings in six types of university courses," Journal of Educational Psychology, vol. 82, no. 2, pp. 250-259, 1990.

[29] L. Kremer-Hayon, Teacher self-evaluation: teachers in their own mirror (Vol. 37). Springer Science \& Business Media, 1993. 
[30] A. M. Zafarghandi, et al., "The effect of EFL teachers' extrovert and introvert personality on their instructional immediacy," International Journal of Applied Linguistics and English Literature, vol. 5, no. 1, pp. 57-64, 2016.

[31] A. Sun and X. Chen, "Online education and its effective practice: A research review," Journal of Information Technology Education, vol. 15, no. 2, pp. 175-183, 2016.

[32] S. Bal-Taştan, et al., "The impacts of teacher's efficacy and motivation on student's academic achievement in science education among secondary and high school students," EURASIA Journal of Mathematics, Science and Technology Education, vol. 14, no. 6, pp. 2353-2366, 2018.

[33] E. M. Almarghani and I. Mijatovic, "Factors affecting student engagement in HEIs-it is all about good teaching," Teaching in Higher Education, vol. 22, no. 8, pp. 940-956, 2017.

[34] A. Khan, et al., "Effect of personality traits and learning styles towards students' academic achievement in Johor Bahru," International Journal of Engineering and Technology, vol. 7, no. 2, pp. 4-9, 2018.

[35] I. Wandini and O. Abdurahkman, "The relationship between the teacher personality competencies and the attitude of the learner," Didaktika Tauhidi: Jurnal Pendidikan Guru Sekolah Dasar, vol. 5, no. 1, pp. 53-69, 2018.

[36] M. Sholehhudin and H. J. Waluyo, "Evaluating the use of multicultural-based short story appreciation textbook to teach prose-fiction appreciation course," International Journal of Instruction, vol. 13, no. 1, pp. 831-844, 2020.

[37] N. Friesen, "Experiential evidence: I, we, you," In Hermeneutic phenomenology in education. Brill Sense, 2012, pp. 39-54.

[38] C. Moustakas, Phenomenological research methods. Sage Publications, 1994.

[39] U. Kramer and A. Pascual-Leone, "Self-knowledge in personality disorders: an emotion-focused perspective," Journal of Personality Disorders, vol. 32, no. 3, pp. 329-350, 2018.

[40] F. M. van der Kleij, "Comparison of teacher and student perceptions of formative assessment feedback practices and association with individual student characteristics," Teaching and Teacher Education, vol. 85, no. 1, pp. 175-189, 2019.

[41] K. K. Bhagat, et al., "The impact of personality on students' perceptions towards online learning," Australasian Journal of Educational Technology, vol. 35, no. 4, pp. 73-85, 2019.

[42] N. Munthali, et al., "Innovation intermediation in a digital age: Comparing public and private new-ICT platforms for agricultural extension in Ghana," NJAS-Wageningen Journal of Life Sciences, vol. 86, no. 1, pp. 64-76, 2018.

[43] J. Jovanović, et al., "Learning analytics to unveil learning strategies in a flipped classroom," The Internet and Higher Education, vol. 33, no. 4, pp. 74-85, 2017.

[44] A. C. Vallberg Roth, "What may characterise teaching in preschool? The written descriptions of Swedish preschool teachers and managers in 2016," Scandinavian Journal of Educational Research, vol. 64, no. 1, pp. 1-21, 2020.

[45] R. Castillo-Gualda, et al., "The role of emotional regulation ability, personality, and burnout among Spanish teachers," International Journal of Stress Management, vol. 26, no. 2, pp. 146-152, 2019.

[46] A. Canales and L. Maldonado, "Teacher quality and student achievement in Chile: Linking teachers' contribution and observable characteristics," International Journal of Educational Development, vol. 60, no. 1, pp. 33-50, 2018. 